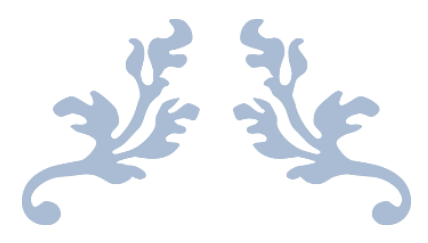

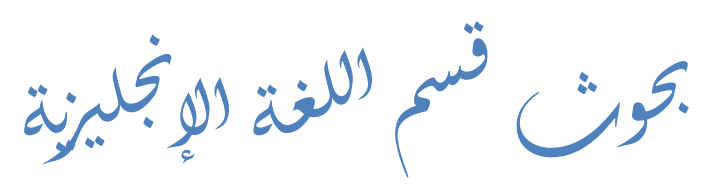




\title{
A Corpus-Based Transitivity Analysis of Covid-19 Editorials in Egyptian and Chinese Media
}

\author{
Ahmed Abdelhafiz Mohamed Hassan, \\ Anhui International Studies University, China
}

mailto:ahmed.abdelhafeez33@gmail.com

\section{Abstract:}

In this study, the authors analyze Transitivity relations in covid-19 editorials selected from Egyptian and Chinese newspapers. The research relies on the use of computational Systemic Functional Linguistics for the analysis as the UAM CorpusTool is used for the analysis of the data. The Data consists of twelve editorials covering Covid-19 related topics. These editorials were drawn from two Egyptian newspapers: Al-Ahram Weekly and The Egyptian Gazette, and two Chinese newspapers: China Daily and Global Times. These four newspapers represent two different types of newspapers, namely Broadsheet and Tabloid, respectively, and they are state-owned newspapers published in English. The analysis tackles types of processes, participants, and circumstantial used in these editorials. 


\section{Key Words:}

Editorials, Newspapers, News texts, Transitivity, Covid-19, Coronavirus, and Systemic Functional Linguistics. تحليل التعدّية في المقالات الافتتاحية عن فيروس كورونا في وسائل الإعلام المصرية والصينية

\section{الملخص:}

يقوم الباحث في هذه الدراسة بتحليل التعدي في اثني عشرة مقالة افتتاحية عن فيروس كورونا في وسائل الإعلام المصرية والصينية. والنظرية المستخدمة في التحليل هي نظام التعدي

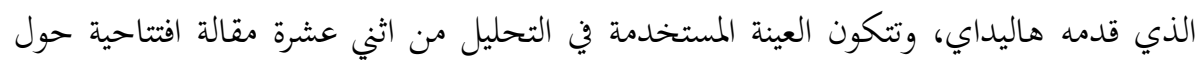

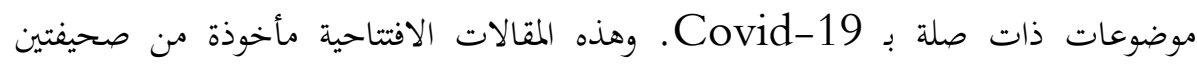

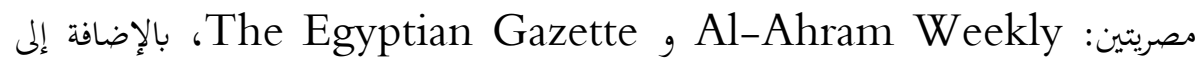
صحيفتين صينيتين: China Daily و Global Times. تمثل الأربع صحف نوعين مختلفين من الصحف: صحف برود شيت وصحف التابلويد، وهم جميعاً صحف منشورة باللغة

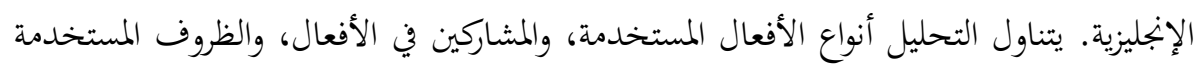

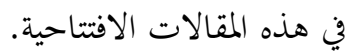

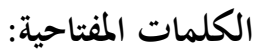

التعدي، الدلالة، مقالات افتتاحية، فيروس كورونا، علم اللغة الوظيفي، علم تحليل النص. 


\section{Introduction:}

Editorials are the manifestation of a newspaper's ideology. Although a single editor usually writes them, the opinions represented in them are institutional. Editorials discuss opinions and conerns with their readers, who use these editorials to make up their mind about world events. Unlike other news texts, editorials offer a piece of news in the form of a discussion, which may or may not appeal to the reader's views on the matter.

Despite their influence on public opinion, editorials have not been adequately studied by linguists. Van Dijk (1996) argued that most work on editorials is written by former journalists (Fischer \& Fischer, 1990; Rystrom, 1994), who were trying to cover the press's opinion on a single historical event (Bagdikian, 1968), or foreign policies (Chang, 1989; Myers, 1982a, 1982b). Most of the work on editorials is focused on American and British newspapers. However, in this study, English-language editorials published by Chinese and Egyptian newspapers are the main scope.

The twelve editorials selected for this study are drawn from four established newspapers. The Egyptian newspapers include Al-Ahram Weekly and The Egyptian Gazette, whereas the Chinese newspapers include China Daily and Global Times. The editorials focus on Covid-19 related issues, and they offer their respective newspapers' ideology about that matter. The analysis of these editorials uses Halliday's (1994) Transitivity system as part of the Systemic Functional Linguistics theory. The analysis is carried out using the annotation tool UAM CorpusTool v.3.3, which allows statistical data production. This 
statistical data are compared to find the different linguistic strategies used in newspapers from Egypt and China.

2. Theoretical Framework and Literature Review

2.1. Theoretical framework:

Transitivity refers to the system describing the whole clause, rather than just the verb and its object as focused on by transitivity in traditional grammar (Thompson, 1996). Eggins (2004) describes Transitivity as the combination of "processes, participants and circumstances carried out by the content words of clauses" (213). These processes, participants, and circumstances are classified into different types that are significantly important for constructing the meaning, and scheme of a text as a whole .

Halliday classified processes into six different process types: material, mental, verbal, relational, existential, and relational. Each of these processes expresses a different meaning relation. Halliday's classification can be summarized in the following table: 
Table 1: Process types, their meaning, and key participants (Halliday, 1994, p: 143)

\begin{tabular}{|l|l|l|}
\hline Process type & Category meaning & Participants \\
\hline $\begin{array}{l}\text { Material: } \\
\text { Action, event }\end{array}$ & $\begin{array}{l}\text { Doing, Happening: } \\
\text { e.g. kick, run, paint, repair, } \\
\text { send, burn }\end{array}$ & Actor, Goal \\
\hline Behavioural & $\begin{array}{l}\text { Behaving: } \\
\text { e.g. cry, smile, glare }\end{array}$ & Behaver \\
\hline $\begin{array}{l}\text { Mental: } \\
\text { Perception, } \\
\text { Affection, } \\
\text { Cognition }\end{array}$ & $\begin{array}{l}\text { Sensing, Seeing, Feeling, } \\
\text { Thinking: } \\
\text { e.g. see, hear, know }\end{array}$ & Senser, Phenomenon \\
\hline Verbal & $\begin{array}{l}\text { Saying: } \\
\text { e.g. say, tell, warn, argue, } \\
\text { ask }\end{array}$ & Sayer, target \\
\hline $\begin{array}{l}\text { Relational: } \\
\text { Attribution, } \\
\text { Identification }\end{array}$ & $\begin{array}{l}\text { Being, Attributing, } \\
\text { Identifying: } \\
\text { e.g. be, have, become }\end{array}$ & $\begin{array}{l}\text { Carrier, Attribute, } \\
\text { Identified, Identifier, } \\
\text { Token, Value }\end{array}$ \\
\hline Existential & $\begin{array}{l}\text { Existing: } \\
\text { e.g. be }\end{array}$ & Existence \\
\hline
\end{tabular}

As shown in Table 1, participants' roles differ according to the different process type used. The process type determines the relationship between participants and their role in the whole action.

Different types of circumstances add information about time (when), place (where), manner (how), and reason/cause (why, for what/who), among others. These circumstances can be probed with questions that could be answered by that circumstance. 
Table 2: Types of circumstance in English (Matthiessen, 2011, p: 4)

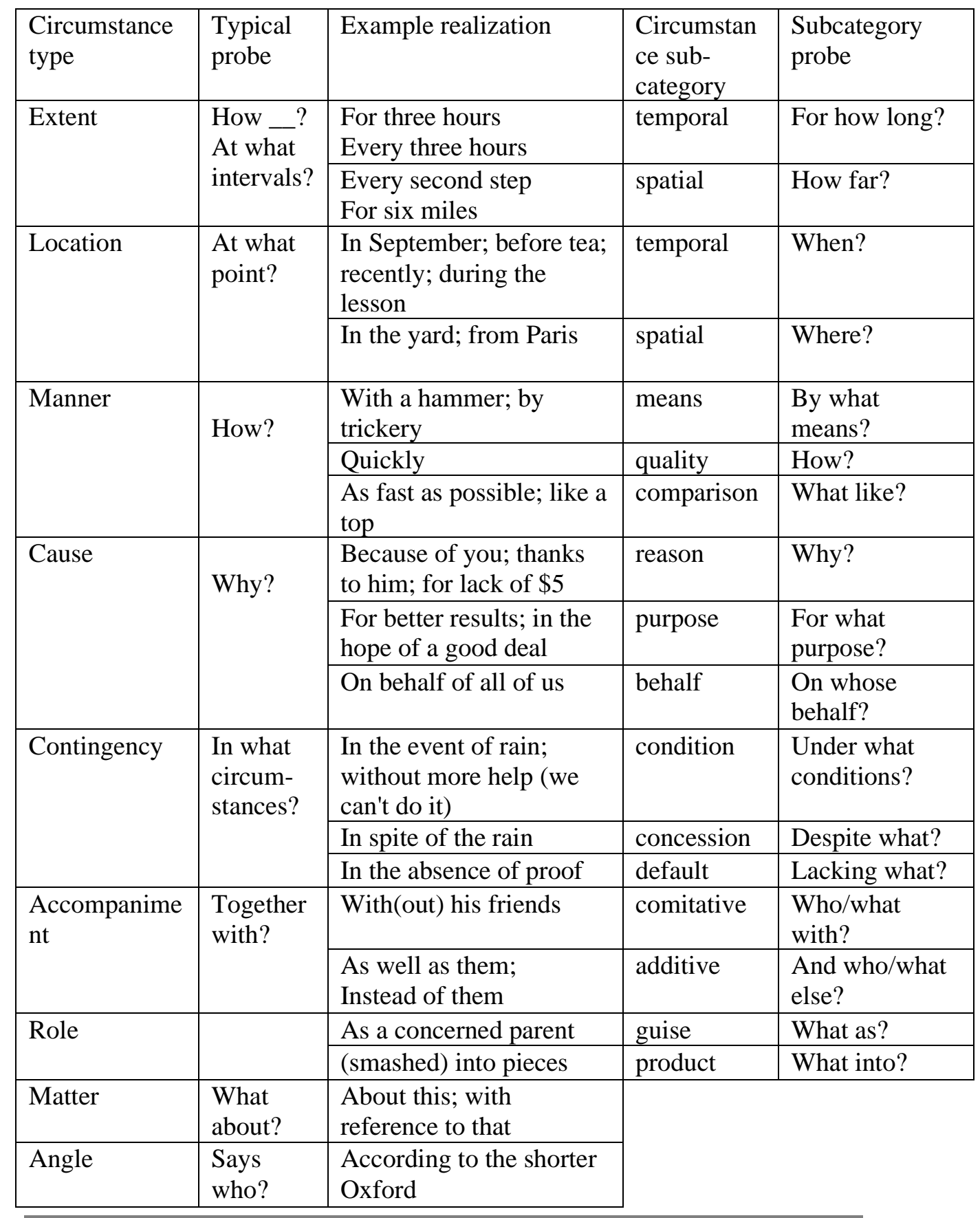


After having discussed the constituents of a clause according to the transitivity system, let us discuss the data collection and the analysis procedure of this research.

\subsection{Literature review:}

Systemic Functional Linguistics has been used for Discourse Analysis since its emergence in the 1950s. The researcher has used Halliday's proposed systems for the analysis of different contexts. Transitivity is one of the systems that were extensively researched over the last couple of decades. Researchers from different countries used Transitivity to explore the representation of their countries' images in foreign media (Viscido, 2014; Tang, 2018; Leung and Huang, 2007; Wu, 2006), and effects of the linguistic choices on influencing how the people think about international affairs (Manheim and Albritton, 1984; Wanta et al., 2004; Zhang and Meadows, 2012). Several studies relied on the transitivity system for the analysis of news texts. Jóhannsdóttir (2018) stated in his research on Iceland press that online traditional newspapers are shaped by their institutional norms. Noor (2017) studied online newspapers in Malaysia, integrating Critical Discourse Analysis and Systematic Functional Linguistics.

Since the emergence of Computational SFL, studies have made use of computational tools for the analysis of research corpora. These tools have facilitated the analysis process, and made it easier to analyze large corpora in less time. These tools were used for the analysis of various fields, ranging from education (Aika, 2017; Machado, Armas, 2017; Munalim, 2017) to healthcare (Crosthwaite, Cheung, and Jiang, 2017).

3. Data collection and Methodology: 


\subsection{Data collection:}

As for the choice of the newspapers, one of the aims of the research is to investigate the different linguistic choices between newspapers in Egypt and China. The editorials that are selected for this study discuss Covid-19 related topics. This topic has dominated newspapers since the beginning of 2020 until the time of writing this research report. Egyptian and Chinese newspapers have been reflecting their institutional ideologies about the matter, and the analysis of the selected data is expected to uncover the similarities and differences between the covering of the Covid-19 related topics in the newspapers of the two countries.

As for the choice of the newspapers, Al-Ahram weekly is one of the leading English newspapers in Egypt and is published by Al-Ahram publishing house as a Broadsheet newspaper. On the other hand, The Egyptian Gazette is the oldest English-language newspaper in the Middle East, and is published as a Tabloid by another established household in the field media organization; El Tahrir Printing and Publishing House. The Egyptian Gazette has both a daily and a weekly edition; the daily edition is called The Egyptian Gazette whereas the weekly edition is called The Egyptian Mail. These two newspapers were chosen due to their historical importance, the number of readers, and influence on public opinion.

Global Times is an English-language Tabloid that follows the People's Daily newspaper, and it has a circulation of over 200,000 copies. China Daily is an English-language Broadsheet owned by the publicity department of the Chinese Communist Party. It has the widest print circulation of any English-language newspaper in China (Hartig, 2017). These four newspapers represent 
the top Broadsheet and Tabloid newspapers in their countries and greatly influence their readers.

\subsection{Methodology:}

The current research relies on UAM CorpusTool version 3.3 for the analysis of text corpora. This Corpus tool has an integrated Transitivity Scheme that is used as a layer for the analysis. UAM is used because it is able to conduct automatic annotation of English grammatical structures and the parts of speech conained in the text. The Transitivity scheme identifies five ranks of grammatical units:

1- Participants

2- Processes

3- Circumstance

4- Configuration

5- Configuration-complex

Figure 1: SFL-Transitivity Scheme in UAM CorpusTool 


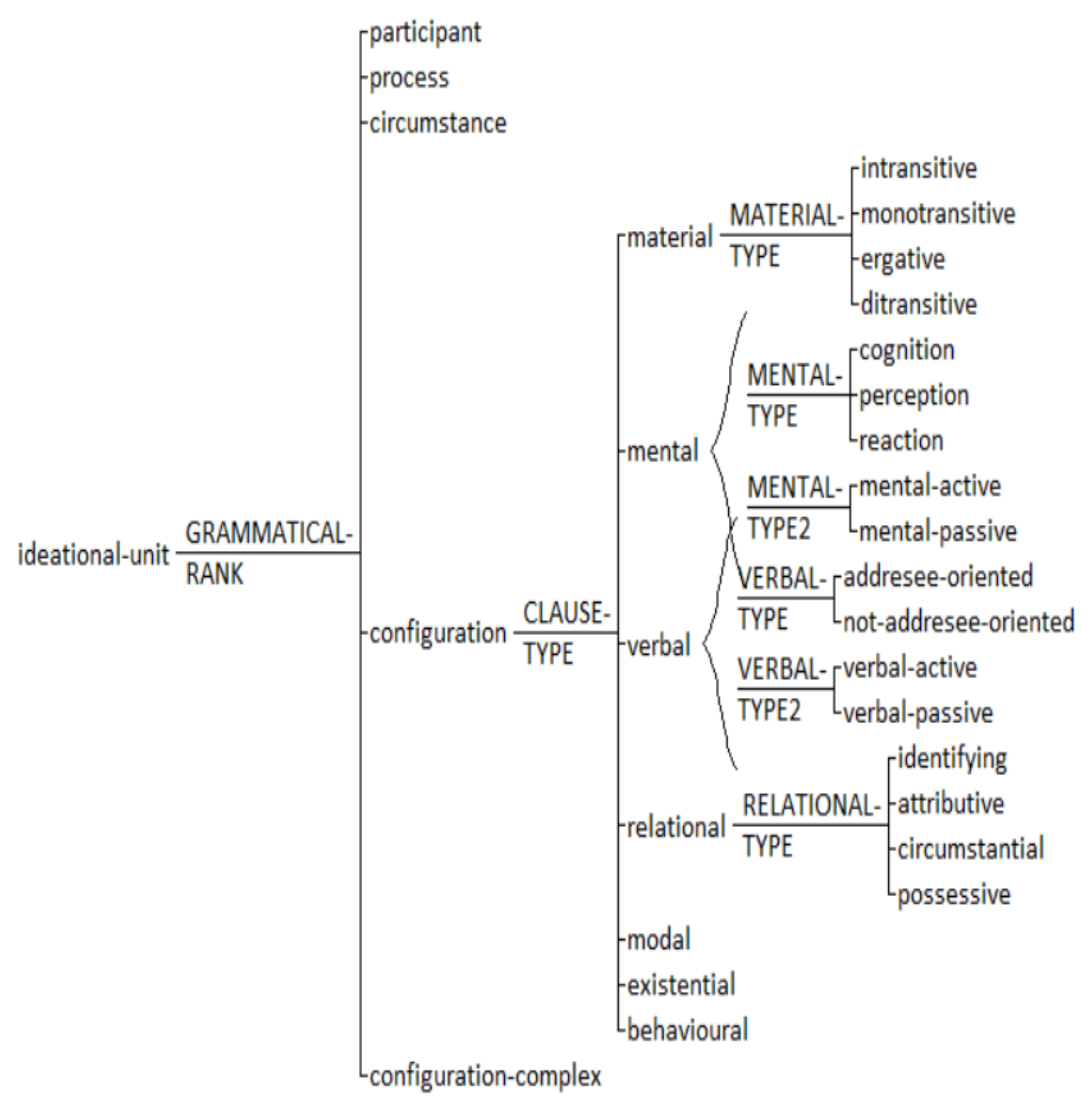

Particpants are the entities that take part in the action; either as the doers of the actions, or the ones affected by these actions. Processes refer to the segments that carry the action itself. Circumstance adds information about time, place, manner, and reason/cause. The remaining two grammatical ranks refer to the classification of processes. Whereas Configuration refers to the classification of processes into a specific process types, configurationcomplex refers to those processes which can be associated with more than one processes type and which require the researcher to determine the process type according to the context. 
After setting the scheme, UAM could offer an annotation of the research corpora based on the scheme chosen. It recognizes segments according to their corresponding grammatical rank: participant, process, or circumstance. The CorpusTool also configures the clause type into the six different process types, and it offers configuration-complex, if present.

In this study, the researcher investigates the balance between different grammatical units. It also offers a classification of these units into their subcategories, which, in turn, offers more detailed results about the linguistic choices made in these editorials.

Figure 2: Example of SFL-Transitivity analysis in UAM CorpusTool:

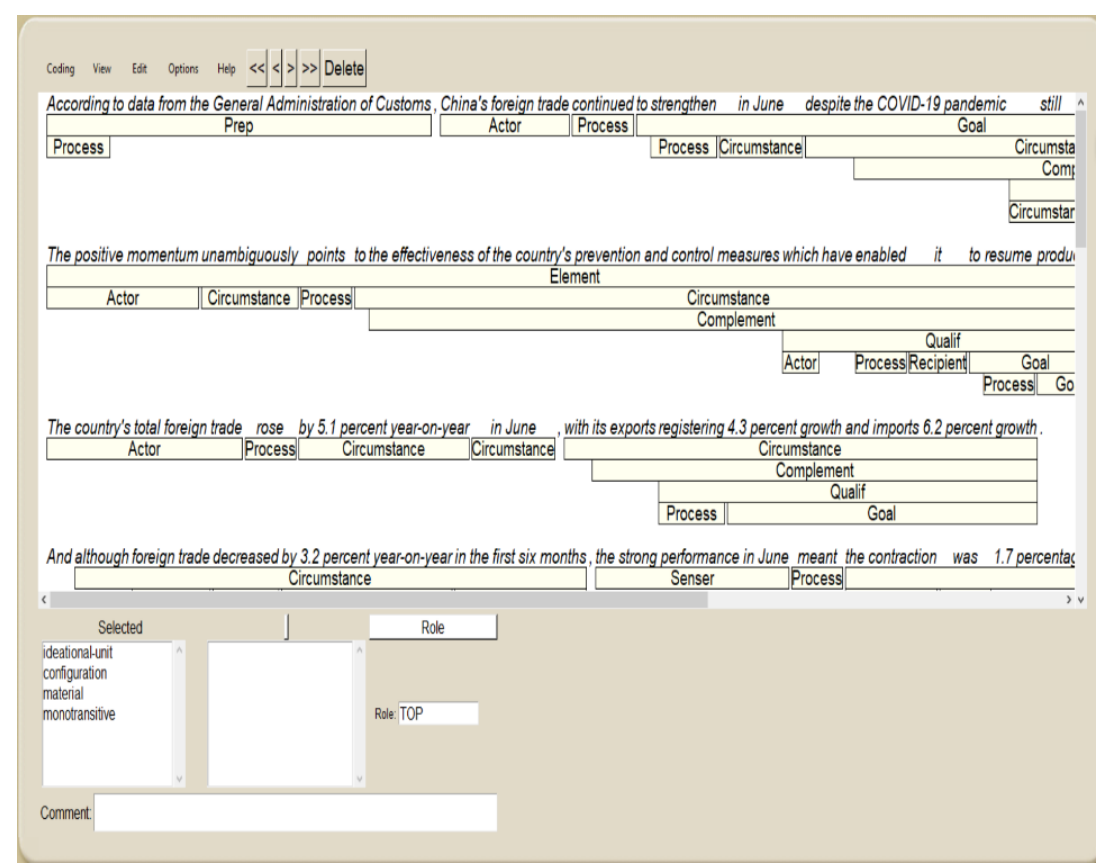

The results are presented in two groups: analysis results of the Egyptian editorials and analysis results of the 
Chinese editorials. The results are then compared to find the different norms that these editorials applied in dealing with this topic. The UAM CorpusTool also allows the researcher to compare the two sets of results.

\section{Data analysis and findings:}

The twelve editorials are added to a single project in the UAM CorpusTool but are divided into two groups to provide separate results for newspapers from each country. The results are represented collectively, with no intent to compare the results of each editorial separately. Newspapers from the same country will not be compared as well, as the main aim of this research is to investigate the different linguistic choices used in each country rather than the different linguistics choices in editorials from the same country.

The analysis starts by using the SFL-transitivity Scheme to assign each segment to its corresponding rank of grammatical units, with a discussion of the significance of these results. Afterwards, the processes in the editorials are classified into the six different process types to find the frequency of each of these process types. The final part of the analysis configures the participants used in these editorials to find the most frequently used participant types.

An initial look at the results provided in the tables below shows that these results give an insight into the linguistic choices that the editors believed were suitable for the topic at hand. The first step in presenting the results of data analysis is investigating the frequency of each of the five ranks of grammatical units.

Table 3: Grammatical rank in the editorials 


\begin{tabular}{|c|c|c|c|c|c|c|}
\hline \multirow{2}{*}{$\begin{array}{l}\text { GRAMMATICAL- } \\
\text { RANK }\end{array}$} & \multicolumn{2}{|c|}{$\begin{array}{l}\text { Chinese } \\
\text { editorials }\end{array}$} & \multicolumn{2}{|c|}{$\begin{array}{l}\text { Egyptian } \\
\text { editorials }\end{array}$} & \multirow[b]{2}{*}{\begin{tabular}{|l} 
Significa \\
nce
\end{tabular}} & \multirow[b]{2}{*}{$\begin{array}{l}\text { Effect } \\
\text { Size }\end{array}$} \\
\hline & $\mathrm{N}$ & $\%$ & $\mathrm{~N}$ & $\%$ & & \\
\hline - participant & 430 & 28.3 & 431 & 28.3 & & 0.000 \\
\hline - process & 423 & 27.8 & 419 & 27.5 & & 0.007 \\
\hline - circumstance & 306 & 20.1 & 325 & 21.4 & & 0.030 \\
\hline - configuration & 360 & 23.7 & 347 & 22.8 & & 0.021 \\
\hline $\begin{array}{l}\text { - configuration- } \\
\text { complex }\end{array}$ & 0 & 0.0 & 0 & 0.0 & & \\
\hline TOTAL: & 1519 & $100.0 \%$ & 1522 & $100.0 \%$ & & \\
\hline
\end{tabular}

It can be seen in Table 3 that the number of participants is more than the number of processes with a small margin due to the extensive use of monotransitive and intransitive material processes. This margin should have been bigger but the UAM CorpusTool included some nominalized verbs in the results, which led to the high percentage of intransitive verbs as well. This reflects the authors' focus on participants that carry out the actions and the goals of these actions rather than on the actions themselves. Moreover, the frequent use of circumstances also reflects the authors' attempt to maintain a simple approach, without using processes that would shift the readers' focus from the main action/event.

The results in table 3 show that participants are the most occurring grammatical rank in both sets, followed by processes. Circumstances are also used frequently in the editorials. Editorials from Egypt and China showed very close percentages in all of the five different grammatical ranks, which reflects that they both follow the same norms in this area of analysis. According to Van Dijk (1995), an editorial should have the following schematic categories: 
1- Summary of past events

2- Evaluation of events

3- Pragmatic Conclusion (Recommendation, advice, warning).

Material processes form the main part of the first and third schematic categories, while the second schematic category makes use of the relational and mental processes. As for the processes used in the editorials, they are classified in table 4:

Table 4: Clause types in the editorials

\begin{tabular}{|c|c|c|c|c|c|c|}
\hline \multirow{2}{*}{ CLAUSE-TYPE } & \multicolumn{2}{|c|}{$\begin{array}{l}\text { Chinese } \\
\text { editorials }\end{array}$} & \multicolumn{2}{|c|}{$\begin{array}{l}\text { Egyptian } \\
\text { editorials }\end{array}$} & \multirow[b]{2}{*}{$\begin{array}{l}\text { Significa } \\
\text { nce }\end{array}$} & \multirow[b]{2}{*}{$\begin{array}{l}\text { Effect } \\
\text { Size }\end{array}$} \\
\hline & $N$ & $\%$ & N & $\%$ & & \\
\hline - material & 225 & 67.0 & 249 & 75.7 & +++ & 0.193 \\
\hline - mental & 31 & 9.2 & 19 & 5.8 & + & 0.132 \\
\hline - verbal & 19 & 5.7 & 27 & 8.2 & & 0.101 \\
\hline - relational & 44 & 13.1 & 25 & 7.6 & ++ & 0.182 \\
\hline - modal & 0 & 0.0 & 0 & 0.0 & & \\
\hline - existential & 17 & 5.1 & 9 & 2.7 & & 0.121 \\
\hline TOTAL: & 336 & $\begin{array}{l}100.0 \\
\%\end{array}$ & 329 & $\begin{array}{l}100.0 \\
\%\end{array}$ & & \\
\hline
\end{tabular}

$+++=$ The statistical significance is of high level

$++=$ The statistical significance is of medium level

$+=$ The statistical significance is of low level

Table 4 shows that both sets of editorials are dominated by material processes; however, the Egyptian editorials show a significantly higher percentage of use 
than the Chinese editorials. While the CorpusTool shows that more than $75 \%$ of the whole count of processes in the Egyptian editorials are material, it shows that $67 \%$ of the processes in the Chinese editorials are classified as material processes. The results for the second most frequently used process type in these editorials show some variation. In the Egyptian editorials, the second most frequent process type is the verbal process, which shows the Egyptian newspapers' reliance on quoting other entities rather than offering their comments on the events and situation. On the other hand, the Chinese editorials prefer the relational process as they are used to offer comments on the situation, which shows that they relied on a different approach than the Egyptian editorials.

Mental processes are used more often in the Chinese editorials, showing that they offer opinions and thoughts more frequently than the Egyptian editorials. The mental process analysis shows similar results in the two sets of editorials. After having analyzed the process types, the research offers a classification of the participant types found in these editorials.

Table 5: Participant roles in the editorials

\begin{tabular}{|c|c|c|c|c|c|}
\hline \multirow{2}{*}{ Process } & \multirow{2}{*}{ Participant } & \multicolumn{2}{|c|}{ Chinese editorials } & \multicolumn{2}{|c|}{ Egyptian editorials } \\
\hline & & $\mathrm{N}$ & $\%$ & $\mathrm{~N}$ & $\%$ \\
\hline \multirow{3}{*}{ - material } & Actor & 100 & $23.26 \%$ & 88 & $22.39 \%$ \\
\hline & Recipient & 9 & $2.1 \%$ & 10 & $2.54 \%$ \\
\hline & Goal & 150 & $34.88 \%$ & 163 & $41.48 \%$ \\
\hline \multirow{2}{*}{ - mental } & Senser & 11 & $2.56 \%$ & 11 & $2.8 \%$ \\
\hline & Phenomenon & 9 & $2.1 \%$ & 7 & $1.78 \%$ \\
\hline \multirow{2}{*}{ - verbal } & Sayer & 10 & $2.32 \%$ & 19 & $4.84 \%$ \\
\hline & Verbiage & 8 & $1.86 \%$ & 10 & $2.54 \%$ \\
\hline
\end{tabular}




\begin{tabular}{|c|c|c|c|c|c|}
\hline \multicolumn{2}{|c|}{ الجزء الثالث } & & \multicolumn{3}{|c|}{ كلية الآداب والعلوم الإنسانية } \\
\hline \multirow{4}{*}{ - relational } & Carrier & 51 & $11.86 \%$ & 38 & $9.67 \%$ \\
\hline & Attribute & 54 & $12.56 \%$ & 38 & $9.67 \%$ \\
\hline & Possessor & 10 & $2.32 \%$ & 5 & $1.27 \%$ \\
\hline & DObj & 10 & $2.32 \%$ & 2 & $0.51 \%$ \\
\hline - existential & Existent & 8 & $1.86 \%$ & 2 & $0.51 \%$ \\
\hline \multicolumn{2}{|l|}{ TOTAL: } & 430 & $100.0 \%$ & 393 & $100.0 \%$ \\
\hline
\end{tabular}

The results of the participant roles' analysis show similar frequencies/percentages in both sets of editorials, except for some differences that are following the different percentage for process types in each country's editorials. Having found that the material processes are the most frequently used process type in both sets of editorials, it is accordingly found that the participant roles of the material process are the highest to occur. Among the participants of the material process, Goal show the highest percentage of users, and the percentages could have been higher if not for the high usage of intransitive and monotransitive material processes, as shown in table 6:

Table 6: Types of material processes in the editorials

\begin{tabular}{|l|}
\hline MATERIAL-TYPE \\
\hline - intransitive \\
\hline - monotransitive \\
\hline - ergative \\
\hline - ditransitive \\
\hline TOTAL: \\
\hline
\end{tabular}

\begin{tabular}{|l|l|}
\hline \multicolumn{2}{|l|}{$\begin{array}{l}\text { Chinese } \\
\text { editorials }\end{array}$} \\
\hline $\mathrm{N}$ & $\%$ \\
\hline 52 & 23.1 \\
\hline 137 & 60.9 \\
\hline 33 & 14.7 \\
\hline 3 & 1.3 \\
\hline 225 & $100.0 \%$ \\
\hline
\end{tabular}

\begin{tabular}{|l|l|l|l|}
\hline \multicolumn{2}{|l|}{$\begin{array}{l}\text { Egyptian } \\
\text { editorials }\end{array}$} & \multicolumn{2}{l}{} \\
\hline N & $\%$ & $\begin{array}{l}\text { Significa } \\
\text { nce }\end{array}$ & $\begin{array}{l}\text { Effect } \\
\text { Size }\end{array}$ \\
\hline 49 & 19.7 & & 0.084 \\
\hline 186 & 74.7 & +++ & 0.297 \\
\hline 12 & 4.8 & +++ & 0.343 \\
\hline 2 & 0.8 & & 0.052 \\
\hline 249 & $100.0 \%$ & \\
\hline
\end{tabular}

However, Goal shows a higher percentage in the Egyptian editorials than in the Chinese editorials, which might be due to the high usage of ergative material processes in the Chinese editorials. The results for the participants in the mental process show insignificant 
differences. Furthermore, since verbal processes are more common in the Egyptian editorials, participants of the verbal process are also in line with these results, with higher percentages of Sayer and Verbiage in the Egyptian editorials. On the other hand, participants of the relational process are more frequently used in the Chinese editorials. The direct object (DObj), which is a participant type of the relational process that can be found in both possessive and attributive processes, was used only twice in the Egyptian editorials compared with ten times in the Chinese editorials.

\section{Discussion:}

The study finds out that the distribution of words across the grammatical ranks is similar in China and Egypt. However, the two countries' editorials show some differences in the choice of clauses. Although the most frequently used clause in editorials from both countries type is the material process, the verbal process is the second most used process type in the Egyptian editorials whereas the relational process is the second most used process in the Chinese editorials. As for the type of material clauses used, Chinese editorials use more ergative processes while Egyptian editorials used more monotransitive processes. The participant analysis shows similar results as the percentages of different types of participants in the editorials reflect the results of the process analysis.

\section{Conclusion}

The findings of this research show that the newspapers from the two countries showed similarities and differences in terms of the linguitics choices made. Some of these difference were of high significance and impacted the rest of the choices throughout the texts. Such differences might be 
influenced by the mother tongues in these two countries or by the cultural norms in these countries. These differences require further research to determine whether these choices follow the norms of writing editorials in these two countries' native languages. 


\section{References:}

Aika, M. (2017) A corpus-based analysis of interlanguage pragmatics: A case study of requestive speech acts using UAM CorpusTool Version 3.2. Studies in Pragmatics: $18,48-59$

.Bloor, T., M. Bloor, (2004), The Functional Analysis of English (second edition), London: Arnold.

Butt, et al. (1995), Using Functional Grammar: An Explorer's Guide. Sidney: Macquarie University.

Crosthwaite, P., Cheung, LML and Jiang, F. (2017). Writing with attitude: Stance expression in learner and professional dentistry research reports. English for Specific Purposes, 46, 107-123. DOI:10.1016/j.esp.2017.02.001

Eggins, S., (2004), An Introduction to Systemic Functional Linguistics, 2nd edition. New York: Continuum international Publishing Group

Halliday, M.A.K. (1973). Explorations in the functions of language. London: Edward Arnold.

Halliday, M.A.K. \& Matthiessen, C. M.I.M. (2004). An introduction to functional grammar. Arnold: London.

Halliday, M. A. K., and Hasan R., (1976). Cohesion in English. London: Longman.

Halliday, M.A.K. (1994). An Introduction to Functional Grammar (2nd ed.). London: Arnold.

Halliday, M. A. K., \& Webster, J. J. (2014). Text linguistics: The how and why of meaning. London: Equinox. 
Halliday, M.A.K. \& Matthiessen, C. M.I.M. (1999). Construing experience through meaning: A language-based approach to cognition. Continuum: London, New York.

Halliday, M.A.K. \& Fawcett, R.P. (Eds). (1987). New developments in Systemic Linguistics. London: Pinter.

Hartig, F. (27 November 2017). "China Daily Beijing's Global Voice?". China's Media Go Global. Routledge https://doi.org/10.4324/9781315619668

Jóhannsdóttir, V. (2018). Commercialization in the Icelandic Press: An analysis of hard and soft news in major print and online media in Iceland in times of change. Journalism, 1(17). https://doi.org/10.1177/1464884918768494

Leung, CM, Huang, Y (2007) The paradox of journalistic representation of the other: The case of SARS coverage on China and Vietnam by western-led Englishlanguage media in five countries. Journalism 8(6): 675-697.

Machado,M. \& Armas T. (2017) Lexical Development in Students' Writing While Progressing from B1 to B2 Level of CEFR. Lengua y Literatura en Monografias.com

Manheim, J. B., \& Albritton, R. B. (1984). Changing national images: International public relations and media agenda setting. The American Political Science Review, 78, 641-657.

Matthiessen, C. M.I.M., and Bateman, J. A. (1991) Text Generation and Systemic-Functional Linguistics Experiences from English and Japanese. Pinter 
Matthiessen, C. M. I. M., \& Halliday, M. A. K. (2009). Systemic functional grammar: A first step into the theory. China: Higher Education Press

Munalim, L., O. (2017). Mental processes in teachers reflection papers: A transitivity analysis in Systemic Functional Linguistics. 3L-Language. Linguistics, and Literature: The Southeast Asian Journal of English Language Studies, 23(2): 154-166.

Noor, S. N. F. M. (2017). The Representation of Social Actors in the Graduate Employability Issue: Online News and the Government Document. International Journal of Society, Culture \& Language, 5(1), 82-93. https://doi.org/http://dx.doi.org/10.1038/s41598-017-02314$\mathrm{x}$

Tang, L. (2018) Transitive representations of China's image in the US mainstream newspapers: A corpus-based critical discourse analysi. Journalism 22 (3): 804-820 https://doi.org/10.1177/1464884918801116

Van Dijk, T. A. (1996). Opinions and Ideologies in Editorials. Paper for the 4th International Symposium of Critical Discourse Analysis, Language, Social Life and Critical Thought, Athens, 14-16 December, 1995.

Villareal, A. C. (2017), CONSTRUCTING MEANING: A SYSTEMIC FUNCTIONAL REVIEW OF TRANSLATED HEALTH TEXTS AND COMMUNITY NARRATIVES (Ph.D.). University of Houston.

Viscido, F. (2015). Any port in a storm: A systemic functional analysis of linguistic choices of representation in news texts. [Master's Thesis]. Retrieved from 
https://tampub.uta.fi/bitstream/handle/10024/96711/GRAD U-1424262996.pdf

Wanta, W., Golan, G., \& Lee, C. (2004). Agenda setting and international news: Media influence on public perceptions of foreign nations. Journalism \& Mass Communication Quarterly, 81(2), 364-377.

Wu, M. (2006) Framing AIDS in China: A comparative analysis of US and Chinese wire news coverage of HIV/AIDS in China. Asian Journal of Communication 16(3): 251-272.

Zhang, C., \& Meadows, C. W. (2012) International Coverage, Foreign Policy, and National Image: Exploring the Complexities of Media Coverage, Public Opinion, and Presidential Agenda. International Journal of Communication 6 (2012), 76-95 